\title{
Central Italian Coins with “Dionysus / Panther” Types From HiSPANIA UltERIOR
}

CLIVE STANNARD ${ }^{1}$, ALEJANDRO G. SINNER ${ }^{2}$

(1) School of Archaeolgy and Ancient History. University of Leicester. clive@ stannard.info

(2) Department of Greek and Roman Studies. University of Victoria. agsinner@uvic.ca

In Saguntum 46, 2014, pp. 159-180, we published three "Dionysus / panther" coins of the Central Italian Assemblage of the Italo-Baetican series from Catalonia, one of which, from excavations at Cabrera del Mar, must have arrived before $50 \mathrm{BC}$. This led us to explore numismatic and other indices of contacts between central Italy, Hispania Citerior and Ulterior; we concluded that there was little evidence for maritime contact between Citerior and Ulterior, but better evidence, in both cases, of contacts with central Italy.
We now illustrate four further "panthers" from Andalucía, three of which were brought to our attention by Gonzalo Cores Uría, and a fourth from Seville, which appear to be evidence of direct contacts between Ulterior and central Italy, perhaps Minturnae.

Obv. Head of Dionysus crowned with ivy, right; border of dots.

Rev. Panther standing right, its left fore-paw raised to hold a thyrsus over its shoulder; crescent above; border of dots.

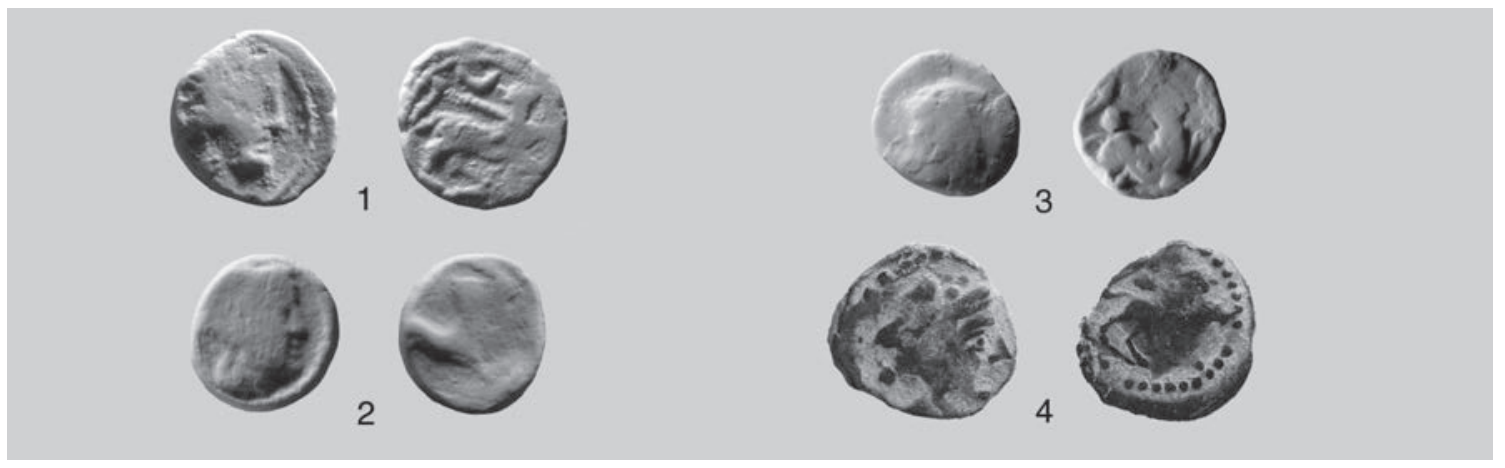

Fig. 1: Dionysus / Panther coins from Andalucía.

Copyright: (C) 2016 Clive Stannard \& Alejandro G. Sinner-This is an open access paper distributed under

the terms of the Creative Commons License, (CC BY-NC-SA 3.0), which permits unrestricted use,

the terms of the Creative Commons License, (CC BY-NC-SA 3.0), which permits unrestricted
distribution, and reproduction in any medium, provided the original author and source are credited. 
1. Æ; $19 \mathrm{~mm} ; 120^{\circ} ; 5.66 \mathrm{~g}$; Collection Cores Uría, Madrid

Same, but no crescent on the reverse.

2. Æ; $17 \mathrm{~mm} ; 30^{\circ} ; 4.40 \mathrm{~g}$; Collection Cores Uría, Madrid

3. Æ; $16 \mathrm{~mm} ; 270^{\circ} ; 5.18 \mathrm{~g}$; Collection Cores Uría, Madrid

4. Æ; $18 \mathrm{~mm} ; 120^{\circ} ; 4.70 \mathrm{~g}$; eBay \#201482170408, January 2016, Numismática Prados, Seville

Coin 5 is also from Andalucía; it was struck by Pseudo-mint A, active in the second quarter of the $1^{\text {st }}$ c. BC (Stannard and Carbone 2013). Pseudo-mints are a phenomenon of the monetary economy of central Italy in the $2^{\text {nd }}$ and $1^{\text {st }} \mathrm{c}$. BC; the term denotes an informal coinage, involving the systematic imitation, over a period of time, by a single emitter, of an issue or issues of one or more foreign mints; this needs to be distinguished from casual imitation, and counterfeiting. These informal coinages responded to a need for bronze small change in a time of rapid economic growth and market development, with the growing wealth of Rome and its allies that resulted from successful warfare.

The largest and earliest pseudo-mint was at Pompeii (c. 140-80 BC ?); it imitated and mixed the types of Ebusus, Massalia, Rome and Athens (Stannard 2013). Pseudo-mint A mixed the types of Panormos and Paestum, and may have been at Minturnae; 5 imitates the types of 6 , from Panormos.

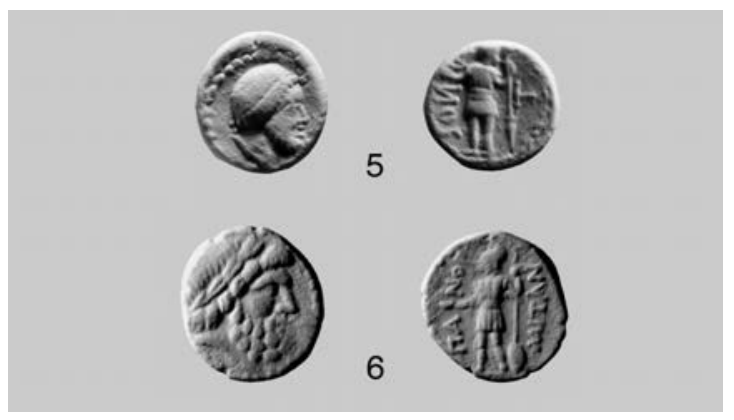

Pseudo-mint A, second quarter of the $1^{\text {st }} \mathrm{c}$. BC ?

Obv. Bearded, diademed male head right; border of dots.

Rev. Helmeted warrior standing half-left, holding patera and spear with head down; T up to right, and SONCA up to left; border of dots.
5. Æ; $15 \mathrm{~mm} ; 60^{\circ} ; 3.27 \mathrm{~g}$; Collection Cores Uría, Madrid; Stannard and Carbone 2013, dies O11/R17

Panormos, Sicily, c. 130/120-90 BC

Obv. Laureate head of Zeus, right.

Rev. Helmeted warrior standing half-left, holding patera and spear; the shield rests against the spear; ПА-NOP-MITAN up to left and right; border of dots.

6. Æ; $17 \mathrm{~mm} ; 240^{\circ} ; 3.70 \mathrm{~g}$; Paris, Seymour de Ricci Panormos 2; Gabrici 1927: 153, 32-35

\section{BIBLIOGRAPHY}

GABRICI, E (1927): La Monetazione del Bronzo nella Sicilia Antica, Palermo.

STANNARD, C. (2013): Are Ebusan and pseudo-Ebusan coin at Pompeii a sign of intensive contacts with the island of Ebusus?, Ebusus y Pompeya, Ciudades marítimas. Testimonios monetales de una relación (A. Arévalo González, D. Bernal Casasola and D. Cottica, eds.), Cádiz, 125-155.

STANNARD, C.; CARBONE F. (2013): Pseudo-mints again: a diestudy, La numismatique pour passion. Études d'histoire monétaire offertes à Suzanne Frey-Kupper par quelquesuns de ses amis à l'occasion de son anniversaire 2013 (S. Frey, ed.), Lausanne: Éditions du Zèbre (Études de numismatique et d'histoire monétaire 9), 255-302. 